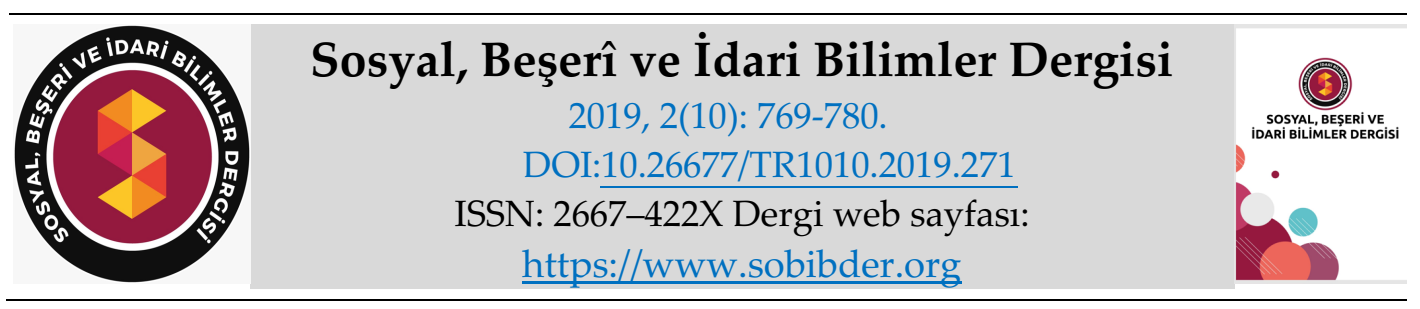

ARAȘTIRMA MAKALESI

\title{
Çardak (Denizli) İlçe Merkezinin Yerleşme Özellikleri*
}

Dr. Öğr. Üyesi Ferdi AKBAŞ, Osmaniye Korkut Ata Üniversitesi, Kadirli Sosyal ve Beşeri Bilimler Fakültesi, Osmaniye, e-posta: ferdi.akbas45@gmail.com

ORCID: https://orcid.org/0000-0003-1899-1458

Öz

Araştırma sahasını teşkil eden Çardak ilçe merkezi Denizli ili topraklarının doğusunda yer almaktadır. İlçe arazisinin doğusunda Dazkırı (Afyonkarahisar), batısında Bozkurt, kuzeyinde Çal, güneyinde Yeşilova (Burdur), güneydoğusunda Başmakçı ilçeleri bulunmaktadır. Çardak, idari bakımdan bağlı bulunduğu Denizli iline 58 km İzmir'e ise 288 km uzaklıkta bulunmaktadır. Araştırma sahasını teşkil eden Çardak ilçe merkezi, Ege Bölgesinin Asıl Ege Bölümü sınırları içerisinde yer almaktadır. İlçede, Akdeniz iklimi görülmektedir. Bitki örtüsü bakımından ise ilçe sınırları içerisinde, hem Akdeniz iklim bitki türleri hem de step bitki formasyonuna ait türler mevcuttur. Araştırma sahasında sürekli akış gösteren bir akarsu bulunmamaktadır. İlçede tarım ve hayvancılık en önemli gelir kaynağını oluşturmaktadır. Araştırma sahasında tarımsal ekonomi geniş bir yer tutmaktadır. İlçe merkezi ve merkeze bağlı mahallelerde halkın \% 80'i tarımla uğraşmaktadır. Hayvancılık faaliyetlerinde ise büyükbaş, küçükbaş, kümes hayvancılığı yoğunluk kazanmaktadır. Tüm bunların yanında çalışma sahasında bir miktar da arıcılık faaliyeti yapılmaktadır. Çardak, tipik bir tarım-hayvancılık kasabası özelliği göstermektedir. İlçe sınırları içerisinde; 13 mahalle yerleşmesi ile aynı zamanda ilçe merkezi konumunda olan bir kasaba yerleşmesi bulunmaktadır. 2018 yılı adrese dayalı nüfus kayıt sistemi verilerine göre, ilçede 9.144 ikamet etmektedir.

* Bu çalışma Ferdi AKBAŞ tarafından tamamlanan yükseklisans tezinden üretilmiştir.

Anahtar Kelimeler: Çardak, Ege Bölgesi, Asıl Ege Bölümü, Kasaba Yerleşmesi.

Makale Gönderme Tarihi: 13.08.2019

Makale Kabul Tarihi: 15.10.2019

Önerilen Atıf:

Akbaş, F. (2019). Çardak (Denizli) İlçe Merkezinin Yerleşme Özellikleri, Sosyal, Beşeri ve İdari Bilimler Dergisi, 2(10): 769-780.

(C) 2019 Sosyal, Beşerî ve İdari Bilimler Dergisi. 


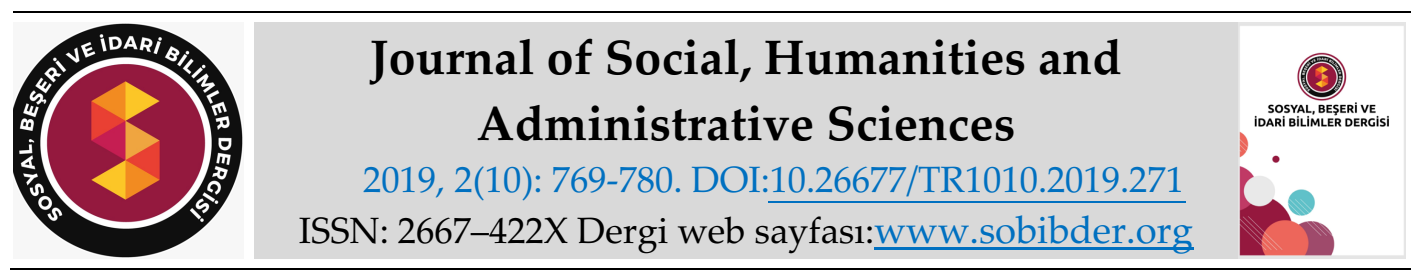

\title{
RESEARCH PAPER
}

\section{Settlement Characteristics of Çardak (Denizli) Town Center}

Assistant Professor Dr. Ferdi AKBAŞ, Osmaniye Korkut Ata University, Kadirli Faculty of Social Sciences and Humanities, Osmaniye, e-mail: ferdi.akbas45@gmail.com

ORCID: https://orcid.org/0000-0003-1899-1458

\begin{abstract}
The study area, district center of Çardak, is located in the eastern territory of Denizli. The district of Dazkırı (Afyonkarahisar) is in the north of the resort, whereas the district of Bozkurt (Denizli) is in the West, Çal is in the North, the district of Başmakçı (Afyonkarahisar) is in the East and the district of Yeşilova (Burdur) is in the South of the town. Çardak District is located $58 \mathrm{~km}$ away from Denizli, which it is legally affiliated, and $288 \mathrm{~km}$ away from Izmir. The district center of Çardak, which is the study ares, is located within the boundaries of actual Aegean Region of Aegean Region. Mediterranean climate is observed in the town. Plant species belonging to Mediterranean and Aegean climates are seen in the district. The vegetation cover consists of maquis and degraded maquis. There is no such a river in the region showing a continuous stream. Agriculture and animal husbandry are the most significant source of income in the district. The agricultural economics occupy a large place in the area. $80 \%$ of the people living in the town center and neighborhoods of the town are involved in agriculture. Cattle and ovine farming as well as poultry are the intense livestock activities. Besides all this, there are a few beekeeping activities in the field of the study. Çardak District shows the characteristics of a typical agricultural county-farming town. The study site is consisted of 13 separate neighborhoods located in the boundaries of the municipality and a town, which is also the center of the district and the settlements. According to the data of address-based population registration system in 2018 , total population of the District is 9.144 .
\end{abstract}

Keywords: Çardak, Denizli, Turkish Aegean Coast, Town Settlement.

Received: 13.08.2019

Accepted: 15.10 .2019

\section{Suggested Citation:}

Akbaş, F. (2019). Settlement Characteristics of Çardak (Denizli) Town Center, Journal of Social, Humanities and Administrative Sciences, 2(10): 769-780.

(C) 2019 Sosyal, Beşerî ve İdari Bilimler Dergisi. 


\section{Gíriş}

\section{Araştırma Sahasının Yeri, Sınırları ve Genel Özellikleri}

Araştırma sahasını teşkil eden Çardak ilçe merkezi, Ege Bölgesinin Asıl Ege Bölümü sınırları içerisinde yer almaktadır. Çardak ilçesi, idari yönden Denizli iline bağlıdır. İlçenin yüzölçümü yaklaşık $227 \mathrm{~km}^{2}$ olup, bunun da yaklaşık $52.4 \mathrm{~km}^{2}$ si araştırma sahasını oluşturmaktadır. Deniz seviyesinden yüksekliği ortalama 864 m olan ilçe merkezinin Denizli şehrine uzaklığ $58 \mathrm{~km}$, İzmir'e ise 288 km'dir. İlçe, matematik konumu itibariyle $37^{\circ} 49^{\prime} 15^{\prime \prime}-37^{\circ} 49^{\prime} 17^{\prime \prime}$ kuzey paralelleri ve $29^{\circ} 39^{\prime} 41^{\prime \prime}-29^{\circ} 41^{\prime} 28^{\prime \prime}$ doğu meridyenleri arasında yer almaktadır. İlçe arazisinin doğusunda Dazkırı (Afyonkarahisar), batısında Bozkurt, kuzeyinde Çal, güneyinde Yeşilova (Burdur), güneydoğusunda Başmakçı ilçeleri bulunmaktadır (Şekil 1).

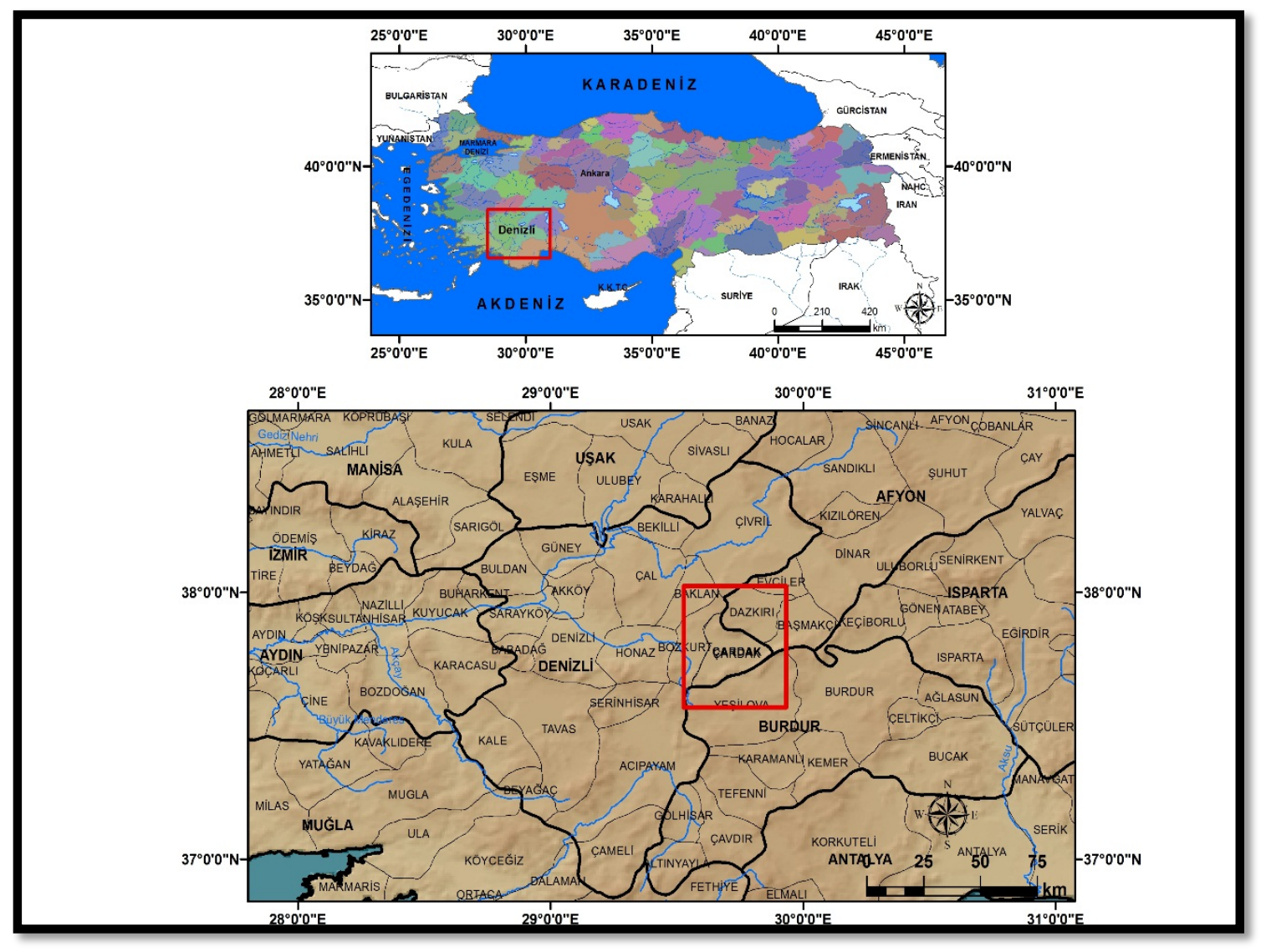

Şekil 1. Araştırma Sahasının Lokasyon Haritası.

Çalışma sahası kuzeyde bulunan Maymun Dağı ile güneyde Söğüt sıra dağları arasında alüvyal yelpaze üzerinde yer almaktadır. Çardak'ta yazlar sıcak ve kurak, kışlar ise ılıman geçmektedir. Çardak ilçesi sınırları içerisinde step bitki örtüsü hakimdir. Sadece kuzeydeki yüksek sahalarda, kızılçam ve ardıçlardan oluşan ormanlara rastlanılmaktadır. Çardak, belediye sınırları içerisinde bulunan 13 tane mahalle yerleşmesinden oluşmaktadır. İlçe sınırları içerisindeki yerleşmelerin tamamı toplu dokulu özelliktedir. Çardak, gerek fizyonomi gerekse fonksiyon bakımından kasaba yerleşmesi özelliği göstermektedir. Araştırma sahası ekonomik faaliyet açısından değerlendirildiğinde, tarım ve hayvancılık sektörleri ön plana çıkmaktadır. Bunların yanı sıra 2. Organize sanayi bölgesinin bulunması, sanayi faaliyetlerinin gelişmesine bir ölçüde katkı sağlamıştır. Çardak havaalanının da ulaşıma açılması, sanayi faaliyetlerinin gelişmesine katkı 
sağlamıştır. Nüfus sayım sonuçlarına göre ilçe merkezinin nüfusu 1960 yılında 1.900 iken 2018 yılında bu değer 9.144 kişiye ulaşmıştır. Bu verilere göre, çalışma sahasının 1960 yılındaki aritmetik nüfus yoğunluğu $4.75 \mathrm{kişi} \mathrm{/} \mathrm{km²,} 2018$ yılında ise 40,2 kişi / km²'dir. Çardak'ta nüfus yoğunluğunun düşük görülmesi, saha yüzölçümünün büyük ve nüfusun az olmasından kaynaklanmaktadır. Bu durum Ege Bölgesinde yer alan kasaba ve şehir yerleşmelerinin tamamında böyle değildir. Özellikle Kıyı Ege tarafında nüfus yoğunluğunun fazla olması $\mathrm{km}^{2}$ ye düşen kişi sayısını arttırırken, İç Batı Anadolu’ya doğru bu durum tam aksi bir biçimde olmaktadır.

Araştırma sahası, Ortaçağ'da geçimini hayvancılıktan sağlayan bir köy yerleşmesi konumundaydı. Maymun Dağı eteğine yerleşen köy halkı, hayvanlarını sıcaktan korumak maksadıyla meskenlerinin ön ya da yan taraflarına Çardak adı verilen gölgelikler yaparak hayvanlarını güneşten korumaya çalışmışlardır. Bu küçük Türkmen köyünün güneyinde yer alan kervan yolundan geçen diğer köylüler de buraya 'Çardaklı Köy' adını vermişlerdir. Köylüler tarafından verilen bu isim yerli Türkmen halkı tarafından da benimsenmiş ve böylece araştırma sahasının adı Çardak olarak kalmıştır. Çalışma sahasına bir dönem Frigyalılar hakim olmuş bundan sonra da ilçe Selçuklularının egemenliği altına girmiş ve bu dönemde araştırma sahası savunma merkezi konumunda kullanılmıştır. Selçuklulardan sonra Çardak'a İnançoğulları ve Germiyanoğulları hakim olmuştur. Sultan Yıldırım Bayezit döneminde Germiyanoğullarının çalışma sahasındaki hakimiyetine son verilerek saha Osmanlı İmparatorluğu topraklarına katılmıştır. 1402 yılındaki Ankara Savaşı'ndan sonra Moğollarının egemenliğine giren Çardak, birkaç yıl sonra yeniden Osmanlı İmparatorluğu bağlanmıştır. Çalışma alanı Osmanlı İmparatorluğu'ndan sonraki süreçte Türkiye Cumhuriyeti Devleti'nin kurulmasıyla ilk olarak Dinar'a, sonra Honaz'a ve daha sonraki süreçte ise Bozkır Bucağı'na bağlı bir köy yerleşmesi olarak kalmıştır. 1958 yılında Denizli'ye bağlanan köye, aynı yıl ilçe merkezi statüsü kazandırılmıştır.

Araştırma sahasının temel ekonomik faaliyetlerini tarım ve hayvancılık teşkil etmektedir. Çardak ilçe merkezinin birikinti yelpazesi üzerinde konumlanması tarımın ve buna bağlı olarak da hayvancılık faaliyetlerinin daha da gelişmesine öncülük etmiştir. Tüm bunların yanında çalışma sahasının Söğüt sıradağları ve Maymun Dağı'nın arasında yer alan alçak düzlükte bulunması ve iklimin olumlu etkileri sonucu tarımsal faaliyetler önemli bir gelişme göstermiştir. Araştırma sahasında anason, üzüm, kimyon, ceviz, domates, biber, karpuz yetiştirilmektedir. Bu yetiştirilen tarım ürünlerinin \% 46,1'ini üzüm (sofralık-çekirdekli) oluşturmaktadır. Çardak'ta küçükbaş hayvancllıkta koyun ve keçi, büyükbaş hayvancilıkta ise sı̆̆ır yetiştiriciliği yapılmaktadır. Küçükbaş hayvancılıkta koyun yetiştiriciliği, keçi yetiştiriciliğine oranla daha fazladır. Büyükbaş hayvancılıkta ise kültür sığırı yetiştiriciliği melez ve yerli sığırlardan oldukça fazladır. Bu durum süt verimliliği açısından değerlendirildiğinde, kültür sığırlarından elde edilen sütün melez sığırlardan alınanlardan fazla olduğu ortaya çıkmaktadır. İlçede yer alan süt toplama merkezi hayvancılığın sürdürülebilirliği açısından büyük önem taşımaktadır. Çardak havaalanının kurulması ve faaliyete geçmesi, 2. Organize sanayi bölgesinin de aktif konuma getirilmesi Çardak'ta, ekonomik faaliyetlerin canlanmasına bir miktar katkıda bulunmuştur. Araştırma alanının sınırları içerisinde kalan Acıgöl'den elde edilen sodyum-sülfatın deterjan, cam, boya, kozmetik ve deri sanayisinde kullanılması Çardak'ın ekonomisine büyük katkı sağlamıştır. 


\section{YERLEŞME}

\section{Yerleşmenin Tarihi Gelişimi}

Nüfus çalışmalarında yerleşme tarihi de oldukça önemli konulardan biridir. Nüfus ve yerleşme birbirinden bağımsız düşünülemez (Doğan, 2009: 4). Antik dönemde Lampe Ovası olarak bilinen vadideki yerleşim, Gölcük Köyü Höyüğü, Gemişpınar Höyük ve Beylerli Höyüklerinden Prehistorik dönemlerde başlayıp günümüze kadar devam etmiştir. Bizans Döneminde Charax adıyla tanınan Çardak, Honaz Kalesiyle Soublaion (Siblia) Kalesi yol güzergâhında bulunmaktadır. Anadolu'nun Türkleşme sürecinde 11-13. yüzyıllarda yoğun Selçuklu-Bizans mücadelelerine sahne olmuştur. Bizanslılar tarafından güvenlik amacıyla Maymun Dağı'nda yer alan kale kullanılmıştır (Denizli Valiliği, 2001: 1-25). Araştırma sahasında bilinen en eski yerleşim birimlerinden biri olan Gavur Kalesi, ilçenin kuzeyinde yer alan Anava (Acıgöl) gölü ve Hanbat (Çardak) Ovası'na hakim bir tepe üzerinde kurulmuştur. Savunması çok kolay, ele geçirilmesi çok zor olan dik bir tepe üzerinde kurulmuş olan bu kalenin kimler tarafından, hangi tarihte yapıldığı hakkında, arkeolojik çalışmalar yapılmadığı için sağlıklı bilgilere sahip değiliz. Ancak, eldeki bulgular bu kalenin Roma İmparatorluğu zamanında yapıldığı hakkında bilgi vermektedir. Çardak ilçesinde Romalılar tarafından kurulan ve bir kasaba büyüklügüünde olan Anava hakkında kesin bilgiler bulunmamaktadır. Bu antik Anava şehrinin tarihi yol üzerinde Anava (Acıgöl) kenarında olduğu Evliya Çelebi'nin Seyahatnamesinde dile getirilmekle birlikte, bu şehrin Maymun Dağı'nın eteğinde mi, yoksa Başmakçı tarafında gölün başlangıç noktasında mı, ya da Gemiş, Gölcük tarafında mı olduğu konusunda tam bir araştırma yapılmamıştır. Bu konu arkeolojik çalışmalar sonrasında aydınlatılabilecektir. Denizli'de Türkler ilk defa 1070 senesinde görünmeye başlamışlardır. Selçuklu Sultanı Alparslan'a karşı karşı isyan eden Selçuklu beylerinden Erbasganoğlu'nu yakalaması için görevlendirilen Afşin Bey asi Selçuklu beyini bulamayacağını anlayınca, süratle batıya doğru hareket ederek, zamanın büyük ve gelişmiş şehri Honaz'1 fethetmiştir (1070). Bu arada Denizli ve çevresi de Kutalmışoğlu Süleyman'ın maiyetindeki beyler tarafından fethedilmiştir. Ancak, bu fetih kalıcı olmamıştır. Denizli ve çevresi Bizanslılarla Türkler arasında 12.yüzyılın ortalarına kadar sürekli olarak el değiştirmiştir. Anadolu'nun Türkleşmesi açısından büyük öneme sahip olan 1176 yllındaki Miryakefalon (Kumdanlı) Savaşı'ndan sonra Türkmenler, Denizli sınırına yayılmışlardır. Bu tarihten itibaren Türk hakimiyeti, Denizli'nin doğu kısımlarında yerleşmeye başlamış ve devam eden tarihlerde ise Denizli çevresi Bizanslılar eliyle tahrip edilerek Türk hakimiyetine geçiş çabuklaştırılmıştı. Çardak'ın fethedilmesi de bu süreçte gerçekleşmiştir. Bizans Ordusunun Burdur'u ele geçirmesi ve Isparta yakınlarına kadar ilerlemesi üzerine Selçuklu Sultanı, Osman Bey ve Hüsamettin Bey komutasındaki bir orduyu bölgeye göndermiştir. Bunların komutasındaki Türk birlikleri Satırlar, Karaağaç (Acıpayam) Ovası, Karaatlı, Gençali ve Çivril Gümüşsuyu Kasabası sınırları içerisindeki Düzbel'i, Bayındır, Gölcük, Beylerli, Cumalı, Köpekbeli ve Çambaşı Köyü fethedilmiştir. Buraların ele geçirilmesinden sonra Mahmut ve Seyyid Bey komutasındaki Türk birlikleri Hanbat (Çardak) Ovası'nı Bizanslılardan tamamen temizledikten sonra, Bozkurt üzerinden Baklan'a doğru hareket etmişler, sonra da Çivril ve Çal bölgesinin fethine girişmişlerdir (Kodal, 2006: 1-10). Böylece bu dönemde Çardak Türklerin eline geçmiştir. Denizli dolayısıyla Çardak, Selçuklu Sultanı II. Kılıç Arslan'ın ölümünden sonra Bizanslıların eline geçmekle beraber diğer Türkmenlerin de yardımıyla, 1207'de Anadolu Selçuklu Devleti'ne kesin olarak katılmış ve vali olarak Esede'd-din Ayaz atanmıştır (Denizli Valiliği, 2001: 1-12).

Çardak'ın da içinde bulunduğu Denizli ve çevresinin Anadolu Selçuklu Devleti'nin eline geçmesiyle Türkleri yenilgiye uğratarak, Anadolu'dan atmak ve Hiristiyanlık için önemi büyük 
olan Kudüs'ü ele geçirmek amacıyla yapılan haçlı seferleri sırasında Çardak, Büyük Menderes Vadisi'ni takip eden tarihî yol üzerinde bulunması nedeniyle, II. Haçlı Seferi (1147-1148) sırasında Türk-Haçlı mücadelelerinin yaşandığı bir yer olmuştur. Anadolu Selçuklu Devleti'nin 1243 Kösedağ Savaşı'nda Moğollara (İlhanlılar) yenilmesiyle birlikte Denizli ve yine Çardak, bağımsız davranmaya başlayan Türkmenlerin yönetimine geçmiştir. Türkmenler beyleri arasındaki ihtilafları iyi değerlendiren İlhanlılar tarafından, Ali Bey Denizli'ye "bey" olarak atanmıştır. Denizli ve çevresindeki Türkmen beylerinin zayıf durumlarından faydalanan Germiyan Oğulları, Denizli ve çevresini yine aynı şekilde Çardak'ı 1288'de yönetimleri altına almışlardır. Germiyanoğulları Beyliği, Kütahya merkez alınarak kurulmuş, İç Batı Anadolu'da geniş bir alanı kaplamıştır. Bu nedenle, Denizli ve çevresi de Germiyanoğullarına bağlı İnançoğullarının denetimi altında kalmıştır.11 Germiyanoğullarının Denizli ve çevresindeki egemenliği, Germiyanoğullarının Osmanlı Devleti'ne ilk olarak bağlandığı 1391 yılına kadar devam etmiştir. Anadolu Selçuklu Devleti'nin çöküşünden sonra, Anadolu' da başlayan karışıklıklar 14. yüzyılın ortalarına kadar sürmüştür.Osmanlı Beyliği'nin 1299 yılında kurulması ve güçlenmeye başlamasıyla, Anadolu'nun tümünde değilse bile önemli bir bölümünde bağımsız beylikler ortadan kalkmaya, siyasal ve sosyal ortam, bütünlük kazanmaya başlamıştır. Osmanlı Beyliği'nin büyüyüp "gaza politikası" ile güçlenmesi ile birlikte, Anadolu'nun siyasal birliği konusunda da çalışmalar başlatılmıştır.13 Bu çalışmalar sonunda Denizli'nin de içinde bulunduğu Kütahya sancağı evlenme yolu ile Osmanlı topraklarına katılmıştır. I. Murat'ın 1389 yılında Kosova savaşında öldürülmesinden sonra Denizli ve çevresi Karamanoğulları başta olmak üzere diğer beylikler tarafından işgal edilmiştir. Fakat Yıldırım Bayezit, Candaroğlu Süleyman geçmiştir. Yıldırım Bayezit'in yenilgisiyle sonuçlanan Ankara savaşından sonra Denizli, önce Timur $n$ Paşa'nın da yardımıyla, Denizli'yi 1391 yılında fethetmiş,böylece şehir ilk defa Osmanlılara tarafından, daha sonra da Timur'un Anadolu'yu terketmesiyle, Germiyanoğullarınca 1403 yılında egemenlik altına alınmıştır. Böylece Denizli'deki ilk Osmanlı hakimiyeti sona ermiştir. Fakat, Denizli üzerindeki Germiyan egemenliği önce 1411'de Karamanoğullarınca, sonra da 1429 yılında Osmanlılarca ikinci kez ortadan kaldırılmıştır. Bu tarihten itibaren Denizli ve çevresi dolayısıyla Çardak, Cumhuriyet dönemine kadar Osmanlı Devleti'nin yönetimi altında kalmıştır.Osmanlı Devleti'nin I. Dünya Savaşı'nı kaybetmesi ve Mondros Mütarekesi'ni imzalamasından sonra, Türk toprakları emperyalist devletler tarafından Mondros Mütarekesi'nin 7. maddesi gerekçe gösterilerek işgal edilmiştir. Bu nedenle, Türk milleti Mustafa Kemal Atatürk'ün önderliğinde Kurtuluş Savaşı'nı başlatmıştır. Yunanlılar İngilizlere vermiş olduğu sözü tutmak, "Şark Meselesi" ni yani Türk sorununu çözüme kavuşturmak ve kendi rüyalarını gerçekleştirmek amacıyla, Denizli'nin Buldan vb. yerlerini yani Kuzey-Batı taraflarını barbarca kendi yönetimleri altına almışlardır.Ancak, Denizli Merkez de dahil olmak üzere Çardak Yunanlılar tarafından işgal edilmemiştir. İşgal edilmemesine rağmen Çardak da Denizli Müdafaa-ı Hukuk Cemiyeti'ne her türlü desteği vermiş ve Millî Mücadele'de Mustafa Kemal ve arkadaşlarının yanında yer almıştır (Kodal, 2009: 105-116).

Çardak İlçe merkezi 1105 yılında Maymun Dağı eteğinde Körin adıyla anılan Türkmen aşireti olarak kurulmuş, daha sonra şimdiki yerleşim yerine taşınmıştır. Çardak, Ortaçağda halkın geçimini hayvancılıkla sağladığı küçük bir köy idi. Maymun Dağı eteğindeki köy halkı, hayvanlarını güneş sıcağından korumak amacıyla; evlerin ön taraflarına veya yan taraflarına Çardak denilen gölgelikler yaparak önlem almaktaydı. Bu küçük Türkmen köyünün hemen güneyindeki kervan yolundan geçen diğer köylüler de, buraya "Çardaklı Köy" adını vermişlerdir. Bu isim yerli Türkmen halkı tarafından da benimsenmiş ve böylece köyün adı Çardak olarak kalmıştır. İlçe tarihinin Frigyalılardan başladığı tarihçilerin eserlerinden anlaşılmaktadır. "Seven Church" Yedi Kilise adlı eserde İran Hükümdarı (Serhas) Keleneyi terk ettiği vakit, Frigya şerhinden (Avana) adındaki bir kasaba yakınından ve tuz çıkarılan bir gölün yanından geçtiğini bahsetmektedir. Ünlü tarihçi Heredot'un da kitabında bahsettiği bu gölün "Acı göl" olduğu ve 
sözü edilen yerleşim biriminin de Çardak olduğu sanılmaktadır. İlçeye Frigyalılardan sonra Selçuklular egemen olmuştur. İlçede bunlar ve daha sonraki uygarlıklara ait kalıntılar mevcuttur. Daha çok ticari ve askeri politika güden Selçuklular, büyük kervan yolu üzerinde Akhan ve İlçedeki Han-i Abad gibi tarihi yapılar inşa etmişlerdir. Çardak Han-i Abad kervansarayı, ilçe merkezinin içerisinde kalmıș durumdadır. Bu kervansaray da diğerleri gibi kervan yolu üzerinde kervanların konaklama yeri olarak yapılmıştır. Han'i Âbâd kervansarayının, tarih araştırmacılarına göre, Selçuklu Sultanı 1. Alaettin Keykubat zamanında 1299 yılında Esüddin tarafından yapıldığı yazılmakta ise de kervansaray kitabesinde "Biribat (Han) Alaettin Keykubat günlerinde Başkumandan Ayaz tarafından 627 yılı Ramazanında yapıldığı" yazılmaktadır. Çardak, Selçuklular zamanında bir uç kalasi olarak, Selçuklular'ın savunma merkezi olmuştur. Anadolu Beylikleri zamanında ise yöre, önce İnançoğulları'nın sonra da Germiyanoğulları'nın eline geçmiştir. Germiyanoğulları Beyliği, Osmanlı İmparatorluğu topraklarına Sultan Beyazıt Han tarafından katılmıştır. Timur, Ankara Savaşı'ndan sonra Çardak'ı ele geçirmiş, askerlerinin bir kısmı ilçede bulunan kervansarayda birkaç yıl kalmışlardır. Timur'un tekrar doğuya çekilmesi ile yörede beylikler dönemi yeniden başlamış, fakat kısa sürmüştür. 1429 yılında tüm yöre Osmanlı İmparatorluğu'na katılarak Aydın Sancağı'na bağlanmıştır (Kodal, 2009: 105-120).

Hali hazırda var olan şehirlerin kuruluşu, gelişimi oldukça farklı şekillerde olmuştur. Bunlardan bazıları köy ya da kasaba konumunda iken zaman içerisinde hızla gelişimini tamamlayarak bugünkü durumlarına ulaşmışlardır (Aydın, 2003: 19). Çalışma sahası da bu evrelerden geçmiş ve bugünkü konumuna erişmiştir. İdari bölümün yeniden düzenlendiği Cumhuriyet döneminde küçük bir köy olan Çardak sırası ile önce Dinar ve sonra Honaz Bucağı'na bağlı kalmıştır. 1 Nisan1958 yılında köy iken ayn tarihte ilçe statüsü ile Denizli ili sınırları içerisine dahil edilmiştir. 1958 yılında ilçe merkezi konumuna yükseltilen Çardak'ın, kara ve demiryolları üzerine bulunması gelişmesinde önemli rol oynamıştır (Çardak Kaymakamlığı, http://www.cardak.gov.tr).

\section{Çardak İlçesindeki Yerleşmelerin Şekil ve Tip Yönünden Ayırımı}

Yeryüzünde yerleşilmiş mekanın tümü fonksiyona göre kullanım alanları halinde örgütlenmiştir. Yerleşme de, böyle bir fonksiyonel tür olarak, konut mekanının örgütlenmesi ve dağılışıdır. İnsanların üçte birini uykuda olmak üzere yaşamlarının büyük kısmını geçirdikleri barınak, ihtiyaçları arasında en üst sırada yer almaktadır (Tümertekin ve Özgüç, 2012: 361-364). Barınmak ya da belirli bir faaliyeti sürdürmek amaciyla bir saha üzerine inşa edilmiş bir ya da birden fazla sayıda meskenden oluşan kümeye yerleşme adı verilmektedir (Birinci, 2007: 55). Bir yerleşim kümesi yerleşim alanı ile bu saha üzerinde insanlar tarafından değişik amaçlara yönelik inşa edilmiş meskenlerden oluşmaktadır. Sürekli veya dönemlik olarak insanın içerisinde barındığı, değişik şekillerde faaliyette bulunduğu her türlü konutlar da tek başına yerleşme sayılmaktadır (Özçağlar, 1997: 1-2).

Yerleşme şekli ve yerleşme tipi birbirinden çok farklı iki ayrı kavram olmasına rağmen günümüzde yaygın olarak birbirinin yerine kullanılmaktadır. Yerleşmeleri bulundukları jeomorfolojik ünitelere, dış görünüm şekil (Fizyonomik) özelliklerine ve sahip oldukları fonksiyonlara göre ayrı ayrı tiplendirebiliriz. Bulundukları jeomorfolojij ünitelere göre; ova, plato, dă̆ eteği basamağı düzlüğü yerleşmeleri gibi tiplendirme yapılabilir. Dokusal şekil özelliklerine göre Türkiye'deki yerleşmeleri; toplu yerleşmeler, dağınık yerleşmeler ve ara şekilli (yarı dağınık) yerleşmeler olarak üç şekilde tiplendirebilmekteyiz (Koday, 2000: 104).

Meskenlerin meydana gelmesinde birtakım faktörlerin müşterek etkisi mevcut olmakla birlikte, bu faktörleri, önemlerine göre doğru bir şekilde sıralamak pek kolay değildir. Meskenler, her şeyden evvel, çevre şartları ile insan ve faaliyetlerinin bir eseridir. Buna göre mesken; çevre 
şartları, yükselti, jeolojik yapı, litoloji, bitki örtüsü, iklim elemanları ile onu inşa edecek insanların gelenek, görenek, istek, mali imkanı ve nihayet ekonomik faaliyetlerin muhassalası olarak kabul edilebilir (Tunçdilek, 1967: 51).

İnsan topluluklarının çevre şartlarını göz önünde bulundurularak seçtikleri mekan parçalarında yerleşmeleri, çevre ile yerleşmeleri arasında karşılıklı bir bağın gerekliliğini ortaya koymaktadır. Yerleşmelerin devam etmesini sağlayan insan toplulukları, zaman içerisinde sosyal, ekonomik, kültürel bakımdan değişmeler göstermektedir (Karakuş, 1996: 63). Çardak'ta yer alan meskenler tipik bir kasaba meskenleridir. Modern kent yaşamının zorunlu kıldığı çok katlı binalar araştırma sahasının her tarafında hakim konumda değildir. Çalışma sahasında yaşayan insanların oldukça büyük bir bölümünün temel geçim kaynağının tarım ve hayvancılık olması mesken tiplerini de etkisi altına almıştır. Öyle ki meskenler temel ekonomik faaliyetlerin yapılmasına imkan sağlayacak ölçüde yapılmıştır. Araştırma sahasında yeryüzü şekilleri, bitki örtüsü gibi fiziki coğrafya faktörleri ve tarım arazilerinin küçük ve parçalı oluşu, tarımsal faaliyet ve sosyokültürel özellikler şeklindeki beşeri coğrafya etmenleri yerleşmelerin şekli ve fonksiyonlarının belli karakter kazanmasında etkili olmuştur. Bütün bu faktörlere bağlı olarak araştırma sahasında yerleşmelerin fonksiyonları ve şekilleri ortaya çıkmıştır.

\section{Fonksiyonel Özelliklerine Göre Yerleşmeler}

Barınmak ya da belirli bir faaliyeti sürdürmek amacıyla bir saha üzerinde inşa edilmiş, bir ya da birden fazla sayıda meskenden oluşan kümeye yerleşme adı verilmektedir. Bir başka ifade ile yerleşme, bir yararlanma ve ekonomik faaliyette bulunma sahasıdır (Koday, 2000: 104). Yerleşme çok çeşitli şekillerde görünür. Göçebe çobanların çadır toplulukları, yarı göçebe çiftçi-çobanların senenin yalnız bir kısmında oturdukları kışlık, yazlık ve güzlük eğreti yerleşmeleri, bunlar gibi mesela yine Anadolu'da rastlanan ve kısmen göçebe yahut yarı-göçebe yerleşme ile sedanter yerleşme arasında bir takım ara tip yerleşmeler gibi görünen mandıra, ağıl, oba, kom, tol, mezraa ve divanlar; sedanter insanların oturdukları münferit ev, münferit çiftlik, mahalle, köy, kasaba ve nihayet şehir yeryüzünde görülen yerleşme şekillerinin başlıcalarıdır (Tanoğlu, 1969: 217).

Ülkemizde yerleşmeler; idari bakımdan köy, il ve ilçe yerleşmeleri şeklinde gruplandırılmıştır. Coğrafi olarak yerleşmeler ise şehir, kasaba, köy ve köyden küçük yerleşmeler şeklinde sınıflandırılmıştır. Araştırma sahası bu gruplara göre değerlendirildiğinde 1 kasaba ve 12 mahalle yerleşmesinden oluşmaktadır. Çalışma sahasındaki yerleşmeler dokularına göre toplu dokulu yerleşmeler grubuna dahil olmaktadır. Araştırma sahasındaki jeomorfolojik üniteler yerleşmelerin dokularına etki etmiş̧ir. Tarım ve hayvancılık faaliyetlerinin yoğun olarak yapıldığı çalışma sahasının kuzeyinde bulunan Maymun Dağı bu faaliyetlerin alanını daraltmıştır. Bu nedenle bu ekonomik etkinlikler düz ve düze yakın yerlerde yapılmakta ve sonuç olarak da yerleşmeler bunların etrafında toplanmaktadır.

\section{Konut ve Konut Tipleri}

\section{Doğal Çevre Özellikleri ve Konutlar}

Yerleşme sürecinin en küçük birimi olan konutlar yerleşmenin ana unsurunu oluşturmaktadır. Konutlar korunma, mahremiyet, depolama, konforun ya da çeşitli değerlerin sergilenmesi gibi işlevlerden biri ya da birkaçını birlikte yerine getirmektedir. Konutlar yerel olarak elde edilen inşaat malzemelerini, içinde yaşayanların toplumsal ve ekonomik ihtiyaçlarını ve çevrenin doğal ortam özelliklerini büyük ölçüde yansıtırlar. Evlerin çatılarının eğim durumu, duvar kalınlıkları, pencere ve oda büyüklükleri, hatta ön cepheler, iklim elemanlarından sıcaklık ve yağışın 
durumuna göre değişmektedir (Tunçdilek, 1967: 50-62). Çalışma sahasındaki konutlarda da iklim, bitki örtüsü gibi çevrenin doğal ortam özellikleri etkin olmuştur. Araştırma sahasında kar yağışları çok nadir görüldüğü için konutların çatılarında saç yerine kiremit kullanılmıştır. Bitki örtüsü sık bir ormandan oluşmadığı ve yağış miktarı az olduğu için ahşap evler bulunmamaktadır. Araştırma sahasının jeolojik özellikleri de konutların inşasında etkin rol oynamıştır. Çalışma sahasında en fazla bulunan ve aynı zamanda da kolay erişilebilen ve maliyeti de düşük olan taş ve tuğla, konutların inşasında birinci derecede kullanılan yapı malzemelerindendir (Fotoğraf 1).

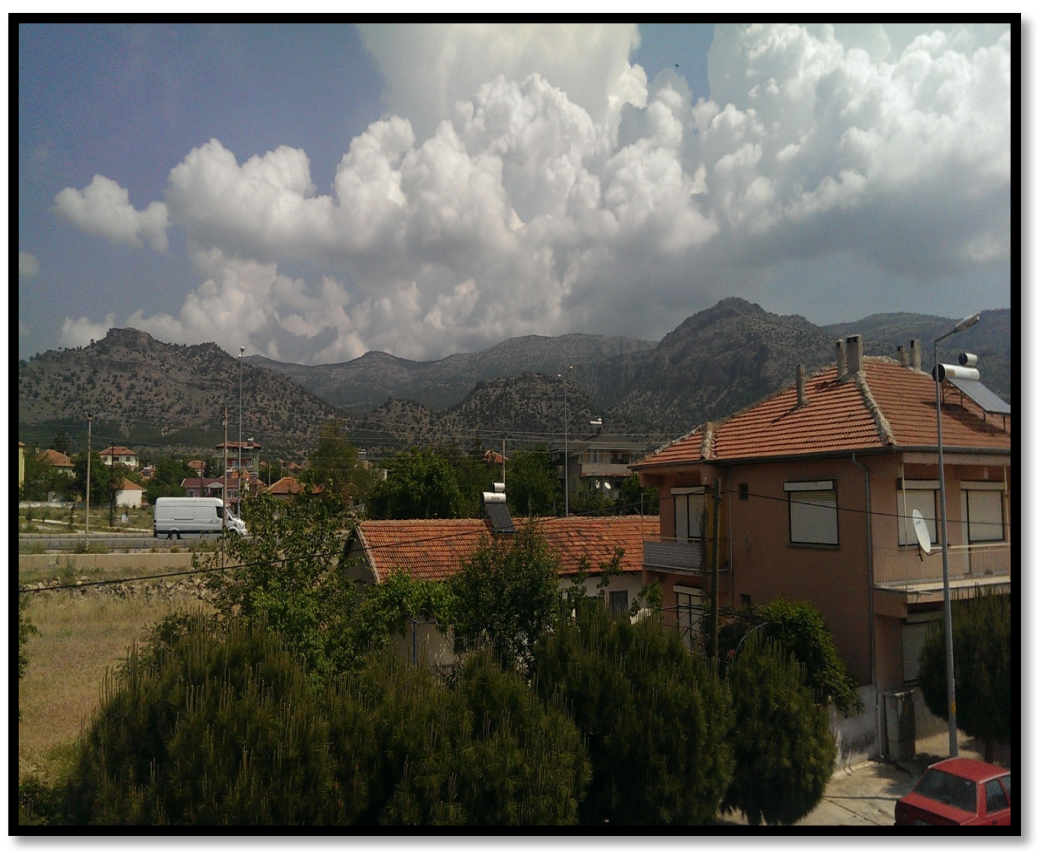

Fotoğraf 1. Taş ve Tuğla Kullanılarak İnşa Edilmiş Konutlardan Bir Görünüm.

Doğal çevre özelikleri konutların inşa edileceği yerler üzerinde etkili olmaktadır. Çalışma sahasının kuzeyinde dağlık ve tepelik kütleler bulunduğu için meskenler düz veya düze yakın alanlarda yapılmıştır. Ancak bu dağlık kütlelerin yakın çevresinde eğimin konut yapımına imkan verecek ölçüde olduğu yerlerde de konutlar inşa edilmiştir. Çalışma alanının genel konut dağılımı incelendiğinde, dağlık ve tepelik alanlar dışındaki tüm yerlerde konutlar eğimin az olduğu düzlük arazide inşa edilmiştir.

\section{Beşeri Çevre Özellikleri ve Konutlar}

Meskenler kullanılan inşa gereçleri, fonksiyonları ve fizyonomileri içinde bulundukları coğrafi mekanın doğal şartlarının yanında, meskenleri kullanan kişilerin ekonomik faaliyet türleri ve sosyo-ekonomik düzeyleri ile yakından ilişkilidir. Nitekim meskenler sadece içinde yer aldıkları doğal çevre şartlarıyla değil, kendini meydana getiren insanların faaliyetlerine, kültürüne, sosyoekonomik şartlarına bağlı olarak da çeşitli şekil ve özellikler kazanmaktadır (Koday, 1995: 1-3). Araştırma sahasında yapılan ekonomik faaliyetler meskenlerin kuruluş aşamasında etkili olmuştur. Başlıca geçim kaynağının tarım ve hayvancılık olması, tarım alanlarının yakın çevresinde evlerin inşa edilmesini sağlamıştır. Çalışma sahasında iki tip mesken bulunmaktadır. Araştırma sahasında bulunan bu meskenlerin bir kısmında hakim ekonomik faaliyetlerin etkisi oldukça belirgin görülürken, diğer kısım meskenler ise modern yaşamın gereklerine göre inşa edilmiştir. 


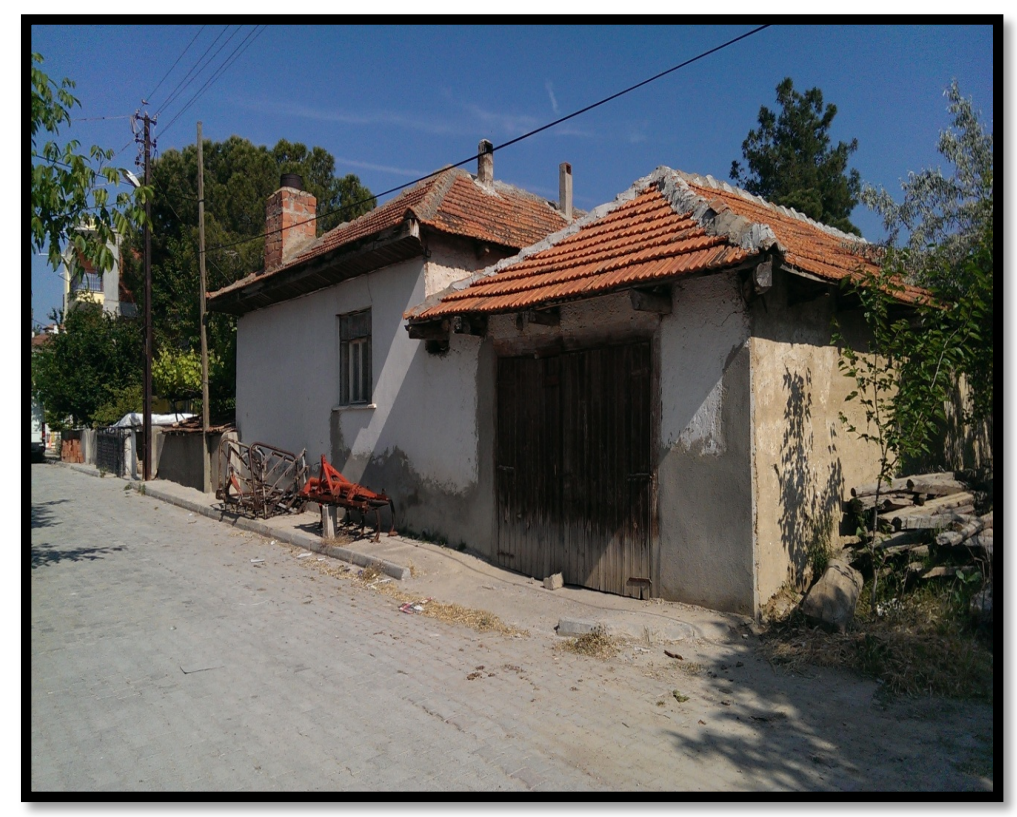

Fotoğraf 2. Çalışma Sahasında Tarım ve Hayvancılık Faaliyetlerin Yapıldı̆̆ı Konutlardan Bir Görünüm.

İlk gruba giren mesken türleri tarım ve hayvancılığa dayalı, halkın ihtiyaçları doğrultusunda eklentileri ile birlikte yapılmıştır (Fotoğraf 2). Diğer grup meskenler ise ikiden fazla katı olan, geniş odaları ve balkonları bulunan yapılardan oluşmaktadır. Çalışma sahasındaki yerleşmelerin oldukça büyük çoğunluğu betonarme konutlardan oluşmaktadır. Ancak araştırma sahasında yığma evler de bulunmaktadır.

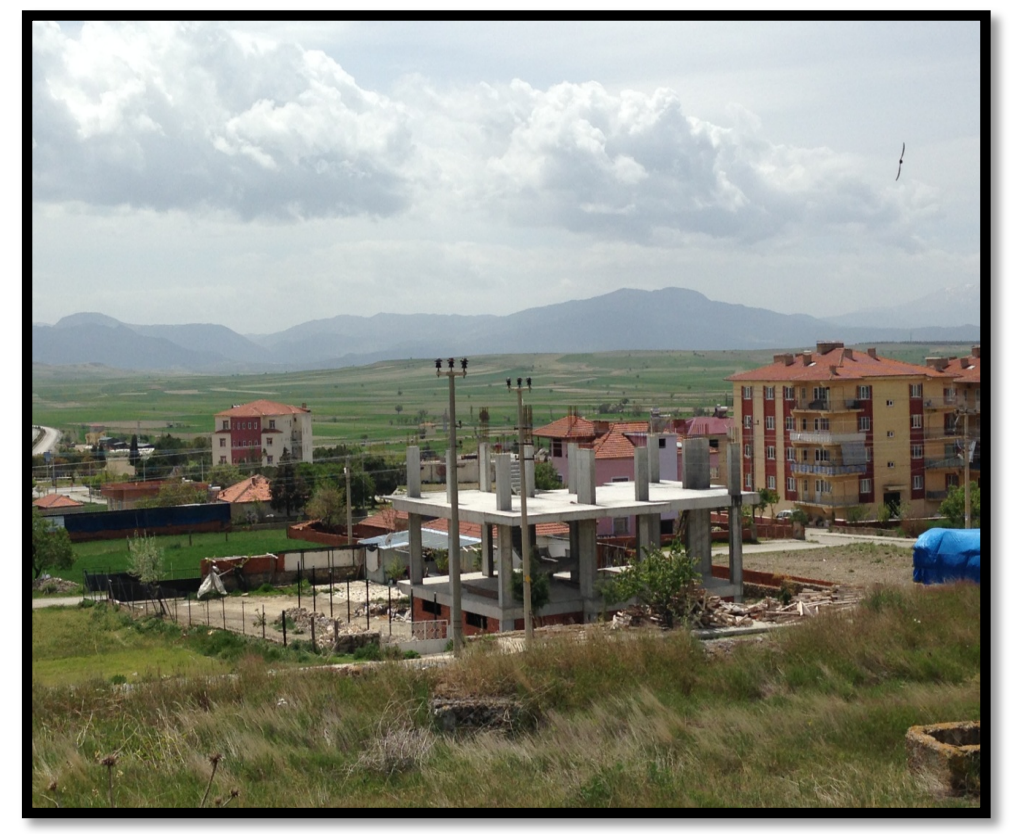

Fotoğraf 3. Çardak'ta Modern Koşullara Göre Yapılan ve Yapımına Devam Edilen Konutlardan Bir Görünüm.

Ailelerin ekonomik durumları iyileştikçe, meskenlerin modernleştiği, oda ve kat sayısının da arttığı gözlenmektedir. Modern yapılar son dönemlerde halkın ekonomik gücüne bağlı olarak inşa edilmeye başlanmıştır (Fotoğraf 3). Bunlardan önceki dönemlerde Çardak ilçe merkezindeki 
evler müstakil statüde yer almış ya da evler en fazla tek kata sahip olmuştur. Yine önceki dönemlerde çalışma sahasındaki evlerin içinde ya da yakınında kümes, ağıl, ambar ve depo özelliği gören eklentiler yer almıştır. Bu ve benzeri yapılar araştırma sahasında hala bulunmaktadır. Ancak eski dönemlerdeki kadar çok değillerdir.

\section{SONUÇ VE ÖNERILER}

Araştırma sahasındaki yerleşmelerin sorunlarının kaynağında doğal ve beşeri faktörler bulunmaktadır. Geçiminin büyük bir kısmını tarımsal faaliyetlerden sağlayan Çardak'ta su konusunda büyük sıkıntılar yaşanmaktadır. Araştırma sahasındaki tarım alanları sulama imkanından yoksun durumdadır. Bu durum da çalışma sahasında kuru tarım yapılmasına neden olmaktadır. Çardak halkı, sulama sorununu bazı yerlerde sondaj yaparak çıkardığı suyu damla ya da yağmurlama sistemiyle kullanarak su sorununun üstesinden gelmeye çalışmaktadır. En büyük ve en önemli sorun olan sulama sorununun bir an önce çözüme kavuşturulması gerekmektedir.

Araştırma sahası bağlı bulunduğu Denizli'ye $58 \mathrm{~km}$ mesafe yer almakta olup bu durum Çardak'ın her yönden gelişmesi için ortam hazırlamıştır. Nüfus olarak kasaba statüsünde olan araştırma sahası, görünüş itibariyle kısmen de olsa ilçeye benzemektedir. Ancak araştırma sahasındaki bağlı mahallelerden bazıları asfalt yola sahip değildir. Bu mahallelerde yollar taş, toprak ve mıcırlarla örtülüdür. Ayrıca çalışma sahasına bağlı mahallelerin bir kısmının kaldırımları da bulunmamaktadır. Çalışma alanının tüm yolları asfaltlanarak, kaldırım ve bordür çalışmaları yapılmalıdır.

Hayvancılık faaliyetlerinin ana geçim kaynaklarından birini oluşturduğu araştırma sahasında, suni gübreler, atık sular, toprak ve ürün gereksinimlerine, besin yönetim planlarına uygun şekilde verilmeli ve planlanmalıdır. Bu önlemler hem zararlı maddelerin yeraltı suları ve besinlere karışmasını engelleyecek hem yerleşim birimlerinin çevre düzenlerinin bozulmamasını sağlayacaktır.. Pestisit kullanımında dikkatli olunmalı ve pestisitlerin bandrollü olması tavsiye edilmelidir. Ayrıca pestisitlerin suya bulaşacağı yerlerde pestisit kullanılmamalıdır. Hayvancılıkla ilgilenenler, hayvanlar için sürekli ve yüksek kalitede, yeterli ve güvenli suyu sağlamalıdır. Ayrıca hayvanlar için alternatif su kaynakları sağlanmalıdır.

\section{KAYNAKÇA}

Aydın, İ. (2003). Demirci Şehri'nin Mekansal Gelişimi ve Gelişimi Etkileyen Faktörler, Marmara Coğrafya Dergisi, 7, 19-44.

Birinci, S. (2007). Eynesil İlçe Merkezinin Coğrafyası, Yayımlanmamış Yüksek Lisans Tezi, Atatürk Üniversitesi Sosyal Bilimler Enstitüsü, Coğrafya Yüksek Lisans Programı. Erzurum.

Büyükoğlan, F. (2010). Honaz Dağı ve Çevresinin Bitki Örtüsü, Kastamonu Ĕ̆itim Dergisi, 18 (2), 631-652.

Denizli Valiliği (1968). Denizli İl Yıllı̆̆ı, Ankara: Ayyıldız Matbaası.

Denizli Valiliği, (2001). Denizli 2001 Kültür Değerleri, Denizli: Deha Matbaası.

Doğanay, H. (1991). Demografya (Nüfus Bilimi), Erzurum: Atatürk Üniversitesi Kazım Karabekir

Eğitim Fakültesi Yayınları. 
Doğanay, H. (1994). Türkiye Beşeri Coğrafyası, (1. Baskı), Ankara: Gazi Büro Kitabevi.

Doğanay, H., Orhan, F. (2014). Şavşat'ta Geleneksel Köy Meskenleri ve Başlıca Sorunları, Atatürk Üniversitesi Sosyal Bilimler Enstitüsü Dergisi, 18 (1), 273-297.

Karakuş, U. (1996). Soma İlçesinde Nüfus ve Yerleşme, Yayımlanmamış Yüksek Lisans Tezi, Gazi Üniversitesi Sosyal Bilimler Enstitüsü. Ankara.

Kodal, T. (2009). Denizli Nüfus Tarihi (1923-2008), (1. Bask1), Ankara: Divan Kitap.

Kodal, T. (2006). Denizli İlçelerinden Çardak'ın İdari Serüveni: Denizli'ye Bağlanması ve İlçe Haline Gelmesi, Pamukkale Üniversitesi Ĕ̆itim Fakültesi Dergisi, (19), 1-10.

Koday, S. (2000). Murgul Çayı Havzasının Coğrafyası, (1.Baskı), Atatürk Üniversitesi Yayın No: 912, Fen-Edebiyat Fakültesi Yayın No: 98, Erzurum: Fen-Edebiyat Fakültesi Ofset Tesisleri. Koday, S (1996). Olur'da Köy Meskenleri, Atatürk Üniversitesi Sosyal Bilimler Dergisi, (23), 187-205. Koday, Z. (2005). Gümüşhane İlinde Nüfus Hareketleri, Atatürk Üniversitesi Sosyal Bilimler Enstitüsü Dergisi, 5(1), 57-69.

Özçağlar, A. (2011). İdari Coğrafya, Ankara: Ümit Ofset Matbaacılık.

Özçağlar, A. (1997). Türkiye'de Belediye Örgütlü Yerleşmeler (Kasabalar-Şehirler), Ankara: Ekol Yayınevi.

Sertkaya Doğan, Ö. (2009). Nüfus Coğrafyası Açısından Bir İnceleme: Silivri, Marmara Coğrafya Dergisi, (20), 1-19.

Tanoğlu, A. (1969). Beşeri Coğrafya Nüfus ve Yerleşme, İstanbul Üniversitesi Yayın No: 1183, Edebiyat Fakültesi Coğrafya Enstitüsü Neşriyatı No: 45, Cilt: 1, İstanbul: Taş Matbaası. Tunçdilek, N. (1967). Türkiye İskan Coğrafyası-Kır İskanı (Köy-Altı İskan Şekilleri), İstanbul: İstanbul Üniversitesi Edebiyat Fakültesi Yayın No :1283, Coğrafya Enstitüsü Yayın No: 49. Tümertekin, E., Özgüç, N. (2012). Beşeri Coğrafya (İnsan, Kültür, Mekan), (13. Bask1), İstanbul: Çantay Kitabevi. www.cardak.gov.tr/index.php?icerik=30, Erişim Tarihi: 10.09.2019. 